\title{
Schools as Agencies of Protection in Namibia and Swaziland: Can They Prevent Dropout and Child Labor in the Context of HIV/AIDS and Poverty?
}

\author{
BJORN HARALD NORDTVEIT
}

\section{Introduction}

This article addresses a particular area of research in the field of education and child protection: the protective role of schools in the contexts of HIV/ AIDS and poverty. Such adverse situations may lead children not to enroll in school or to drop out of school and subsequently to be subjected to abusive child labor and, in some cases, the worst forms of child labor (WFCL). ${ }^{1}$ I argue that the mutually reinforcing relationship of HIV/AIDS and poverty in many countries is leading to increasing child labor and that schools need to respond to this situation through policies that protect vulnerable children from dropping out and from abuse when they are at school. Further, I demonstrate that the HIV/AIDS pandemic has led to a breakdown of traditional and family-based safety networks in many communities, adding to the difficult situation experienced by orphans, children who are heads of families, and children who are caregivers to sick parents. The school emerges as the institution that can take over some of the protective and socializing roles that parents and the community have traditionally provided.

The education literature discussing the relationship between the role of schools in child protection and child labor is limited. ${ }^{2}$ This gap is surprising, especially in the contexts of extreme poverty and high rates of HIV/AIDS, since these phenomena result in many children who do not attend school or drop out of school and become involved in abusive forms of labor at an early age. Many impoverished families are challenged to bear the direct and opportunity costs of children's schooling (ILO 2006). This situation is exacerbated in the context of the HIV/AIDS crisis in that, when parents are

\footnotetext{
${ }^{1}$ The worst forms of child labor are internationally defined by the International Labor Organization's (ILO) convention no. 182 and include slavery; trafficking; debt bondage and other forms of forced labor; and forced recruitment of children for use in armed conflict, prostitution, pornography, and illicit activities (ILO 1999).

${ }^{2}$ In many cases media coverage related to school protection is limited to sensational stories (reminiscent of the media coverage of the Beslan, North Ossetia, school hostage crisis in September 2004 or the shooting episode at the Virginia Polytechnic Institute in April 2007). Similarly, though the child slave-labor camps discovered in China in May 2007 led to widespread media attention, the connection of this event to contemporary discourses about the aims of education was largely ignored.
}

Electronically published February 16, 2010

Comparative Education Review, vol. 54, no. 2.

(C) 2010 by the Comparative and International Education Society. All rights reserved.

0010-4086/2010/5402-0003\$10.00 
incapacitated or die from the disease, there is an even greater need for children not to attend school. Pressure mounts for them to work as agriculture workers, as herders, or-especially for girls-as caregivers for parents and younger siblings (ILO/IPEC 2003). Therefore, child labor, and specifically WFCL, is increasingly a focus for many governments and development agencies (USDOL 2008).

Hence, the research question that I address is, in societal contexts that are characterized by high levels of HIV/AIDS and poverty, what can schools do to encourage enrollment and to prevent dropout, outcomes which in many cases lead to abusive child labor? To respond to this question, I conducted case studies in two countries in sub-Saharan Africa, Namibia and Swaziland.

\section{Theoretical Issues and Related Research}

The literature on child labor distinguishes between abusive "child labor" and acceptable "child work" that "does not affect [children's] health and personal development or interfere with their schooling" (ILO/IPEC 2009, 1). Acceptable child work is generally considered to be something positive and includes such tasks as helping parents and caregivers with household chores and assisting on the family farm or in the family business. In contrast, child labor is defined by the International Labor Organization's International Program for the Elimination of Child Labor (ILO/IPEC) as work that is harmful to children and that interferes with their schooling. ${ }^{3}$

The most abusive forms of child labor, WFCL, include work that exposes children to physical danger; work in an unhealthy environment; and work under particularly difficult conditions, such as carrying heavy workloads, working for long hours, or working at night (ILO 1999). Sex work is another form of WFCL: "For many, it may be the only employment or survival option. While some may freely choose sex work as their occupation, many more young girls, young boys and women are coerced through violence, trafficking, debt bondage or the influence of more powerful adults" (UNAIDS 2006, 37). Often, children's sex work in Africa is related to informal or occasional encounters and sometimes to longer-term involvement with "sugar daddies": "Sell[ing] or trad[ing] sex to meet short-term economic needs (e.g., school tuition, a family financial crisis) . . predominates in most African settings" (UNAIDS 2002, 4).

Literature on child protection focuses on such topics as hunger and poverty, political instability and conflict situations, ill health, and the impact of HIV/AIDS (Foster and Williamson 2000; Harper et al. 2003; Winthrop

\footnotetext{
${ }^{3}$ According to IPEC's definition, child labor "refers to work that: is mentally, physically, socially or morally dangerous and harmful to children; and interferes with their schooling by: depriving them of the opportunity to attend school; obliging them to leave school prematurely; or requiring them to attempt to combine school attendance with excessively long and heavy work" (ILO/IPEC 2009, 1).
} 
and Kirk 2008). Research on the relation between child protection and education is limited. It is related to what Neil Postman (1996) identifies as "engineering" as well as "metaphysical" matters. According to Postman, engineering focuses on practical implementation and access issues rather than on more metaphysical questions about the aims of education. While a number of studies focus on HIV/AIDS's effects on the teacher population or on children's access, attendance, and dropout (see, e.g., Bennell et al. 2002 or project-related documents, such as the World Bank's Staff Appraisal Reports), the literature has also increasingly looked at the metaphysical aspects, such as the need for schools to adapt to a situation of HIV/AIDS and poverty from a curricular perspective (e.g., Brown et al. 2003 and also documents from the UNESCO-led Global Initiative on Education and HIV and AIDS, EDUCAIDS). In particular, EDUCAIDS and similar initiatives recognize that education "contributes to their [orphans' and vulnerable children's] social integration and psycho-social development, protects them from child labour and provides a safe, structured environment in difficult times" (EDUCAIDS $2008,13)$. These initiatives also suggest reforms that can improve the protective function of schools through provision of food and abolition of school fees. These initiatives can "protect orphans and vulnerable children [OVC] by developing school policies and practices to reduce stigma, discrimination, abuse and exploitation" (EDUCAIDS 2008, 14).

A number of studies have suggested that traditional support and solidarity networks in sub-Saharan Africa, often related to children's extended families, may moderate some of the negative effects of losing a parent and may thereby prevent disruption of a child's schooling (Nyamukapaa and Gregson 2005). For instance, in a study conducted in Burkina Faso (which is less affected by HIV/AIDS than most Southern and Eastern African countries), Jean-François Kobiané et al. (2005, 488) found that "parental death is detrimental for children's chances of entering school when they lose both parents, especially in rural areas. For children who had the opportunity to receive support from an extended family, this negative effect is reduced." Nevertheless, while schools may need to play a more important role in protecting children when traditional protection systems break down, in many countries they may not be in a position to do so:

\footnotetext{
Deepening poverty, political instability and conflict situations, recurrent drought, food insecurity, ill-health and the impact of the HIV and AIDS pandemic . . . have given rise to a rapid increase in the number of orphans and children affected by HIV and AIDS in multiple and complex ways, which has further intensified the strain on conventional care and support systems. As a result, we have turned increasingly to delivering services for children through schools and alternative learning centres where they spend a high proportion of their time. Despite some success with this, we now recognise that schools in their current form and mandate are being stretched beyond their original purpose and their current capacities are often insufficient to bridge the gap in service delivery for children. (Bartlett 2008, 1)
} 
The connection between school dropout and child labor is well documented (Dorman 2008). Most of the literature on the aims of education, however, identifies child labor as a problem for education, but it rarely goes beyond the simple statement of this fact. For example, according to the report to UNESCO by the International Commission on Education for the Twentyfirst Century, "the most wide-spread risk to children caused by excessive working hours is the inability to benefit from education" (Delors et al. 1996, 119). The authors of this report do not identify or explore the schools' role in the protection of children from abusive child labor. ${ }^{4}$

At the same time, several international organizations are implementing programs that reconceptualize schools as centers for protection, care, and support for vulnerable children (UNICEF 2007). These initiatives attempt to redefine the core values of schools and make them more responsive to the poverty and crisis situations that many countries face. Using Postman's terms, the programs address engineering as well as metaphysical problems faced by school systems. Thus, in addition to focusing on access and completion, these programs seek to reform the curriculum, provide psychosocial support to vulnerable children, and deal with questions of stigma and teacher abuse, both verbal and physical.

For instance, teachers in the southern part of Africa often use corporal punishment to discipline students, and this practice is especially supported in rural areas (Soneson 2005a). Recent research indicates that corporal punishment is an ineffective and undesirable disciplining method. ${ }^{5}$ Further, it can be contended that it violates children's rights and international treaties, including the United Nations Convention on the Rights of the Child (CRC) and the African Charter on the Rights and Welfare of the Child (ACRWC) (Soneson 2005a). It is likely that the negative effects of corporal punishment in schools are exacerbated if the punishment is targeted at the children most at risk for dropping out of school because it provides such children with an additional incentive to stop schooling and seek a situation that they perceive as "better" elsewhere. Thus, nongovernmental organizations, in particular Save the Children, have argued that the use of corporal punishment does not enhance schools as "protective" institutions and is not consistent with schools' functions as protective learning centers and providers of social services (Soneson 2005a, 2005b).

The literature about children in conflict and postconflict situations addresses issues of education and child protection, but it is also scarce. In one of the few examples of studies in this field, Rebecca Winthrop and Jackie

\footnotetext{
${ }^{4}$ The Delors Commision (Delors et al. , 95) does mention, however, that the child-centered mode of education, which it endorses, implicitly acknowledges the need to prepare the children for a "hostile" or "alienating system."

${ }^{5}$ See, e.g., evidence listed on the World Corporal Punishment Research Web site: http:// www.corpun.com.
} 
Kirk $(2008,640)$ identify four ways in which schools can create a protective space in an unsafe and violent environment: "a return to normalcy, a mechanism for socialization, the provision of a nurturing environment, and as an instrument for coping and hoping." The first aspect seeks to restore a sense of routine in an uncertain world. The second component promotes children's development of appropriate social behaviors through positive interactions at school. The third part calls attention to how schools can provide additional social services and promote children's well being through the creation of a safe and caring environment. The fourth aspect highlights how schools can assist children to "deal with the difficulties in their lives and find reasons to believe in a better future" (Winthrop and Kirk 2008, 641).

UNICEF has created a framework for such schools under the label of "Child-Friendly Schools," based on the principles of the CRC (UNICEF 2004). The components of the UNICEF framework reflect Winthrop and Kirk's (2008) characteristics of protective schools:

Quality learners: healthy, well-nourished, ready to learn, and supported by their family and community;

Quality content: curricula and materials for literacy, numeracy, knowledge, attitudes, and skills for life;

Quality teaching-learning processes: child-centred; (life) skills-based approaches, technology;

Quality learning environments: policies and practices, facilities (classrooms, water, sanitation), services (safety, physical and psycho-social health);

Quality outcomes: knowledge, attitudes and skills; suitable assessment, at classroom and national levels. (UNICEF 2004, 1)

The findings of the two case studies that follow suggest, in ways that are consistent with the characteristics of safe and child-friendly education, some possible avenues to improve schools' mechanisms for protecting their most vulnerable students.

\section{Methodology}

To address the role of schools in protection of children in adverse situations of poverty and HIV/AIDS, I collected data in Namibia and Swaziland during two field trips, in October 2006 and April-May 2008. Each trip lasted about 20 days, and during each trip I visited both countries. ${ }^{6}$ During fieldwork

\footnotetext{
${ }^{6}$ The fieldwork was related to the evaluation missions for a regional project, Reducing Child Labour in Southern Africa (RECLISA), financed by the Education Initiative of the U.S. Department of Labor (USDOL). The Education Initiative aims to reduce WFCL through an increase in educational opportunities for children at risk for engaging in exploitative labor and for children who have been removed from exploitive work situations (USDOL 2007). This article is not based on the findings of the project evaluations. The views expressed within this article are my own and do not necessarily reflect the opinions of USDOL or any other organization. Baogang He $(2006,168)$, using fieldwork in China as an example,
} 
I conducted on-site interviews and group discussions, and consulted key informants with special knowledge about child labor and education. Since the fieldwork focused mainly on the community's interaction with the school services, I used a compressed ethnographic research design, that is, a design that accommodates shortened time lines and multiple sites and that requires that the researcher is already familiar with the field setting (LeCompte and Schensul 1999).

I selected 11 communities in the Caprivi Strip in Namibia and 15 communities in the Lowweld region of Swaziland according to their high indicators of HIV/AIDS, poverty, and child labor. I visited 18 schools and interviewed approximately 80 persons in 24 focus group sessions, using unstructured and semistructured open-ended questions. These interview sessions included 14 groups of children (each focus group averaging five children between ages 8 and 17) and 10 groups of adults (each focus group averaging four people). ${ }^{7}$ Most of the interviewed children were primary school pupils, some of whom had previously been in a work and/or abuse situation. The adult interviewees were teachers, community elders, and religious leaders, facilitators involved in projects combating child labor, as well as parents and caregivers who were beneficiaries of projects combating child labor. ${ }^{8}$

During the children's focus groups, I invited the children to draw pictures of a certain aspect of their lives (illustrating what they were doing in their free time or at school). We then talked about their drawings. The sessions with the adults were generally conducted as a traditional community meeting, with questions, replies, and interaction from the community members. In general, the data collection procedures were built on the principles of feminist research, that is, to conduct interviews in an interactive, dialogical manner that entails self-disclosure on the part of the researcher and fosters a sense of collaboration, as well as using group interviews that provide for deeper probing and reciprocally educative encounters (Creswell 1998). Most of the interviews with adults and young adolescents were conducted in English, while the interviews with younger children were conducted with the help of an interpreter.

discusses the intricacies of combining consultancy and field research, finding that "consultancy provides opportunities to collect materials more quickly and efficiently" and that "scholars will gain an insider's knowledge of the policy-making process." In addition to sharing his positive experience about consulting and evaluation work, however, I discovered that combining research and consultancy might lead to a difficult balance in research ethics (since the role of the consultant is not primarily research) and to uncertainties about the ownership of research data. Hence, in this article I have been very careful not to use any project-related data that could be considered confidential or proprietary of the USDOL or that could be conceived of as being deceptive from a stakeholder/interviewee point of view. The ethical guidelines of ILO/IPEC on research with children engaged in WFCL were used for the research to ensure protection of the children (Edmonds 2003).

${ }^{7}$ Since school holidays and the agricultural season restricted my access to some community members and schools, I did not visit schools and conduct focus group interviews of both adults and children in all of the communities.

${ }^{8}$ Most of the projects were related to RECLISA and, in particular, to activities implemented by the NGOs Save the Children Swaziland and Africare in Namibia. 
The interview questions elicited participants' perspectives on the main obstacles to education as well as the nature of and effectiveness of interventions designed to promote education and combat child labor in the community. Likewise, the discussions probed the effectiveness of the education services in meeting the needs of children who had been withdrawn from a labor situation. As preliminary findings emerged from the research, I discussed them with key informants, including regional social workers, police officers involved in child protection, and child protection specialists from government and international organizations (in particular, from the ILO and UNICEF), asking them to "comment on the findings as they emerge" (Merriam 1998, 204). Finally, I used a combination of methods to explore the case, including coding and analysis of interviews (using NVivo software) as well as the examination of various project documents and survey data, especially from ILO/IPEC.

\section{Case Studies}

The case studies focus on schools' needs for protection mechanisms in view of different hindrances to schooling, including age-related and administrative barriers, direct and indirect costs of schooling, and social issues.

\section{Namibia}

With a population of approximately 2 million people, the southern African country of Namibia is one of the least densely populated countries in the world (Namibia Government 2007). The gross domestic product (GDP) per capita (purchasing power parity [PPP] US $\$$ ), $\$ 5,155$ (in 2007), classifies Namibia as a middle-income country (UNDP 2009). The wealth of the country is concentrated, within a very small elite, however, as demonstrated by one of the highest Gini coefficients (0.74) in the world (UNDP 2008). Income disparities are also reflected in Namibia's high level of unemployment, estimated at 30 percent of the labor force (World Bank 2006), and high poverty rate: 34.9 percent of the population live on US\$1 or less per day, and 55.8 percent live on less than US $\$ 2$ per day (UNDP 2008). Nevertheless, the literacy rate of Namibia is fairly high (87 percent in 1995-2004) and is expected to rise to 90 percent by 2015 (UNESCO 2008).

Although education is said to be free, the Namibia Education Act of 2001 authorizes the schools to establish a "school development fund." Parents and caregivers are expected to contribute to such funds, although under specific circumstances of poverty and/or HIV/AIDS-related problems, they may be fully or partially exempted from contributing. The main barriers to attending school include engineering problems related to school costs and metaphysical problems related to psychosocial needs caused by the traumatic effects of losing family members to HIV/AIDS, coupled with poverty (Terry 2007).

While it is recognized that HIV/AIDS has reached "epidemic proportions" 
in Namibia, there exists no general, nationwide survey of incidence of the disease within the population (Namibia Government 2007). Data from sentinel studies of prevalence among pregnant women are extrapolated to analyze national tendencies. According to the 2008 sentinel report, the prevalence among pregnant women is 17.8 percent, which situates Namibia among the countries with the highest HIV/AIDS incidence rates in the world (Namibia Government 2008).

According to Terry $(2007,23)$, HIV/AIDS and poverty constitute the "root causes of child labor and the WFCL in Namibia. . . . Overall, it is estimated that approximately 8 percent of females and 9 percent of males aged 6-14 are involved in some form of child labor" (Terry 2007). It is estimated that in rural areas 23 percent of children work, mostly on communal farms (Terry 2007). About 18 percent work in their own homes, and 6 percent work in the homes of employers. Only 10 percent of the working children are paid for employment outside their homes (Terry 2007).

Some of the children's work activities have been found to be exploitative, hazardous, and inappropriate for the children's age (Terry 2007), and therefore could be defined as WFCL. ${ }^{9}$ This work includes illegal activities (including being used by adults or older children to commit crimes), forced work on commercial and communal farms, forced work in some households, work in the charcoal production industry, work in loading heavy or dangerous goods from trucks, and work in the fish-processing industry (Terry 2007).

In addition, in the past decade the number of children engaged in "conventional" prostitution has increased substantially (Terry 2007). A "mild" form of child sex work has become common, and, according to a UNICEF staff member, may affect a much larger part of the child population than conventional prostitution: many children have sexual relationships with older men, often referred to as "sugar daddies" or "sponsors" (Haihambo-Muetudhana et al. 2002). The children may not necessarily be given money for their services but may receive cell phones, groceries for their family, clothes, or payment of school fees and for school uniforms. Although these children do not have multiple partners, such sexual relations are, of course, still dangerous because of the possibility that they will become infected with HIV/AIDS, as in a situation of traditional prostitution.

These problems necessitate a greater vigilance by the schools to protect children through a curriculum that can prepare them to recognize and avoid dangerous situations. The Namibian government and education administration, however, have not been able to respond to this challenging situation, even in terms of engineering issues (i.e., providing access to schools with adequate facilities). During my observations in the field in Namibia I noted

\footnotetext{
9 "WFCL do exist in Namibia. . . . By the very nature of WFCL—often illegal and/or concealed by the adults and children involved-there is limited access to information, particularly statistics in Namibia, as it is true for the rest of the world" (Terry 2007, 5).
} 
the dire state of many schools, especially in areas in which poor people reside (e.g., in rural areas of Caprivi). The schools consisted of unstable bamboo and dirt construction with concrete floors, and many lacked appropriate sanitary facilities. Often, children in these areas only attended low-quality primary schools (most interviewees, both children and adults, deplored the quality of both the school infrastructure and the teaching); secondary schools were further away and would necessitate long hours of walking or bicycling to go to school.

Furthermore, school dress codes hit the poorest of the children most harshly. Repeatedly, teachers and school administrators related that children without uniforms (or with torn or substandard uniforms) were ostracized by teachers or other children. According to interviewed children and teachers, this experience led to a feeling of "inferiority" and in some cases discouraged them from attending school or encouraged them to drop out. Another factor deterring access is the demand for school fees, despite the policy that exempts orphans and vulnerable children from paying. According to interviews with school personnel and other Ministry of Education employees, many schools, particularly those located in rural areas inhabited by poor families, could not function if they followed this policy, since most of the children would then be exempted, and the schools would have difficulty operating on a substantially lower budget. Thus, school personnel continue to try to collect fees from all students, even though they realize that this may lead some children to attend irregularly or to drop out altogether.

The Ministry of Education recognizes that it has not been successful in responding to the metaphysical challenges of educating at-risk children. According to a senior official at the National Institute for Educational Development (at Okahandja), the Namibian education system remains highly theoretical, elitist, and exams focused. The official acknowledged that it is inappropriate for the majority of children and especially inappropriate for orphans and vulnerable children: "We were so enthusiastic in the years following the Namibian independence [in 1990]; we thought everything would change. But it remained the same" (interview, May 2008).

This assessment suggests that reforms proposed in a 1993 Ministry of Education and Culture (MEC) document, Toward Education for All, are yet to be fully implemented. ${ }^{10}$ These reforms include restructuring selection and examination procedures as well as reorienting curriculum and instruction from a teacher-centered approach toward a child-centered learning ap-

\footnotetext{
${ }^{10}$ According to senior civil servants at the Ministry of Education, attempts to reform the education system encountered opposition from teachers and some community members who preferred the old system. The teachers' resistance suggests that they did not see the reformed curriculum as relevant to what they hoped would be the children's future or they perceived the new modalities as lowering the educational quality provided. Perhaps also teachers viewed the changes as threatening, or they simply may not have wanted to change, keeping their own interests, rather than their students' interests, in mind.
} 
proach. For instance, in the first chapter, "From Elite Education to Education for All," the main axes of the new approach are outlined as follows: "Where formal education is primarily concerned with sorting and selecting students, it makes sense to concentrate on weeding out those who do not do well or seem unlikely to do well in the future. Where education is for all, however, schools and other programs must focus on facilitating success. Pedagogy, curriculum and assessment must all be designed to permit, encourage and support successful learning" (MEC 1993, 7-8).

Regarding education and HIV/AIDS, Toward Education for All (MEC 1993, 14) noted that education should "go beyond" provision of information about the disease and "help individuals, families, and groups deal with this new and threatening situation." Further, although the term "protection" is not used, schools were to persuade parents that their children "will have a more comfortable and more secure future if [they] attend school than if they remain at cattle posts to look after the herds" (33).

The MEC sought to improve the curriculum to make it more relevant to Namibian children's lives (MEC 1993). This effort included initiatives by the ministry and some international organizations to develop and implement life skills classes as part of the curriculum. While the ministry's skills curriculum was broad and intended for all students, other stakeholders' initiatives targeted specific users or particular topics. For example, Africare provided a curriculum targeted at OVC students at risk of dropping out of school that focused on communities in which the NGO worked. It organized "COPE" (Care, Protection and Empowerment) Clubs and introduced "Heroes Books" (initially developed by UNICEF/Philippi Trust), which assisted OVC students in creating stories depicting themselves as heroes. ${ }^{11}$ Additionally, in 2004 UNICEF launched its Window of Hope program, which along with other life skills programs that it developed (e.g., "My Future, My Choice") was implemented in UNICEF-supported schools. The goal of this program was to help "10 to 14-year-olds increase self-esteem and acquire knowledge and skills to protect themselves against HIV and develop compassion for those living with the disease" (Lewnes 2005, 1).

Teachers interviewed on this matter stated that children tended to view as "useful" the various life skills programs-those initiatives developed by the ministry as well as the efforts of international organizations. A ministry official also explained: "Window of Hope is very good. It teaches life skills to children, and it boosts their self-confidence. They learn that when they say no, it means no [to sexual advances]" (interview, May 2008). Interviewed children con-

${ }^{11}$ A Hero Book is organized into 10 chapters, including the child's presentation of himself or herself, the description of a hero in his or her life, the description of one of his or her first memories, the presentation of his or her family and community, the explanation of "my problem" (i.e., challenges the child faces in his or her life), the description of a "shining moment" of happiness, the explanation of "tricks and tactics" that the child uses to improve his or her life, and finally, "the hero me," in which the child reconstructs himself or herself as a hero. 
firmed this finding and sometimes pointed out specific chapters and topics that they had found particularly interesting and relevant to their lives. For instance, interviewed children (October 2006 and May 2008) confirmed that the COPE Clubs had performed an important social function in that they helped them to "not feel alone anymore."

Schools encountered problems when implementing the life skills curricula, however. For instance, since life skills were not examined subjects, many headmasters tended to relegate them to the least attractive slots of the schedule, and teachers indicated they viewed life skills and other unexamined subjects as less important. As a senior civil servant explained, "The schools are teaching the children to pass exams. There is a pressure on headmasters and teachers that the children get good results at the exams rather than integrated skills" (interview, May 2008). In addition, teachers responsible for conducting skills classes in most cases were required to do so during their free time-added as an extra duty to their already busy schedules, without any incentives or rewards other than in-service training offered by donors.

Thus, in Namibia it appears that schools were not effectively addressing the engineering or metaphysical issues that were faced by children confronted with the dual challenges of poverty and HIV/AIDS. Moreover, it seems that schools were not able to provide safe zones or protective environments for children. Relevant here is that both children and teachers confirmed during interviews that corporal punishment, although forbidden by law, was frequent in schools. Children-particularly orphans and vulnerable children-often indicated that teachers beat them recurrently. One child's statement is illustrative: "I can tell you we're beaten at school, if we come too late, if we fail a test, if we speak in class. It goes on and on in all the classes" (interview, October 2006). The prevalence of corporal punishment was also shown in children's drawings: when asked to draw what they do during their free time, several children chose to draw themselves being beaten. A UNICEF staff interviewee (May 2008) noted that "when corporal punishment was [officially] abolished, nothing was introduced as a substitute. It's the only way of discipline that the teachers know. It has an immediate effect-and the children are obviously scared." According to adult interviewees (mostly civil servants), beatings at school may have encouraged some children to discontinue schooling and instead seek employment in the hope of finding a situation in which they may not be targeted for corporal punishment.

Swaziland

The Kingdom of Swaziland is a small, landlocked country in southern Africa with a population of nearly 1 million. ${ }^{12}$ With a GDP per capita (PPP US\$) income of \$4,789 (2007), Swaziland is classified as a lower-middle-

${ }^{12}$ The population declined to 954,000 in the latest census in 2007 compared to the 2003 estimate of 1,161,219 (USDOS 2008). 
income country (UNDP 2009). The economic disparities in the country are substantial, however. At 0.50 , the Gini coefficient is among the highest in the world (UNDP 2008), and it is estimated that 69 percent of the Swazi population lives in poverty (USDOS 2008). Most Swazis live in rural areas, where overgrazing, soil depletion, drought, and floods are persistent problems.

The HIV/AIDS crisis also affects all aspects of community life, including economic activity. The country has one of the world's highest HIV prevalence rates, affecting some 220,000 people, or about 23 percent of the population (CSO 2007). Accordingly, life expectancy fell from 60 years in 1997 to 45.3 years in 2007, among the world's lowest (UNDP 2009). Death rates in all regions of Swaziland now exceed international standards for emergency (Whalley et al. 2007). As a result, there are an estimated 130,000 OVCs (31.3 percent of all Swazi children in 2004), a number that is expected to increase to 200,000 by 2010 . Moreover, 43.4 percent of households are currently hosting orphans (Whalley et al. 2007). Approximately half of young women in the 25-29 age range are HIV positive and, therefore, their children have a high probability of being orphaned at young age (CSO 2007). The severity of the HIV/AIDS and orphan crisis is partially alleviated by the presence of grandparents and older family members who have been less affected by HIV/ AIDS and have taken up the role as caregivers (Whalley et al. 2007). "In the long-term, the death of grandparents will leave thousands of children with no support structures" (Whalley et al. 2007, 24).

The high incidence of HIV/AIDS and the growing number of orphans have led to an increasing rate of child labor (IRIN 2009). In relation to this trend, a senior Swazi Ministry of Education (MOE) official noted that it was important to raise awareness about child labor among teachers and community members: "Because of HIV/AIDS, 60,000 children are left without parents. They live on their own or with their extended family. This almost always leads to some abuse. It is appropriate to introduce [into the school curriculum] the theme of child labor at this point. When the children start being abused [in terms of workload] - they [the children] should know that it is wrong" (interview, May 2008). The existence of WFCL in Swaziland has recently been officially acknowledged, and the government has gradually implemented measures to reduce child labor. NGO interviewees pointed out, however, that some high-level officials still claim that child labor is an unknown phenomenon in Swaziland since it does not exist in the formal economy. Little is known about the actual number of working children or the number of children engaged in WFCL. The children working in the informal economy, such as herding sheep and goats, weeding fields or cutting sugar cane, or doing hard household work, remain to a large extent invisible to the broader society and, thus, are perhaps not perceived as a problem.

Orphans and vulnerable children confront challenges of access to and remaining in school, which contribute significantly to their very high grade 
repetition and dropout rates (MOE 2009). Parents are expected or required to contribute toward the costs of primary and secondary education through payment of school fees and to a building fund for construction of school facilities (MOE 2009). School uniforms constitute an additional cost burden for children and their families. They are expensive and cannot be made locally because schools require that they be purchased from specific factories. Moreover, many schools require the purchase of several uniforms: one for the winter, one for the summer, one for sports, one for formal occasions, etc. ${ }^{13}$ One interviewee counted 11 different uniform combinations required in his school, and as a teacher explained, "if the children don't have [a] uniform, they are chased from school" (interview, October 2006). This situation may affect OVC students more than other children, since they rarely are able to afford the required uniform(s).

To reduce the cost burden to families, in 2005 the Government of Swaziland introduced free textbooks for all primary school pupils and special bursaries for orphaned and vulnerable children. In addition, OVC students are legally exempt from paying school fees, although this policy is not always followed at the school level. ${ }^{14}$ As a senior official at the Ministry of Education noted: "We have serious problems [of schools requiring] payments of school fees [by] OVC. Many NGOs are working on this issue, but there is no coordinated effort" (interview, May 2008).

Besides these engineering issues, metaphysical challenges are also present. The increasing number of OVC students, who often live in conditions of poverty, leads to the question of how they will be protected, cared for, and socialized. The schools are in a position to take on these roles, but many interviewed aid workers expressed doubts that the education system could effectively adapt to the new situation and change its traditional elitist and exam-focused system. Indeed, the objectives of primary education remain focused on "provid[ing] basic skills in reading, writing and numeracy" and "prepar[ing] children for secondary education" (MOE 2009, 1). ${ }^{15}$ Primary schools still focus on theoretical subjects, such as mathematics, languages, and sciences, while vocational subjects are not introduced before junior secondary education. Primary education is supposed to last 7 years, within the age range of 6 to 13 years.

${ }^{13}$ Several interviewees from NGOs said the school uniform requirements are largely influenced by bribes received by school personnel from garment factories. In other words, the school uniform policy may have as a direct result a net cash transfer from the poorest and most vulnerable in society to corrupt civil servants.

${ }^{14}$ For example, in a school in Swaziland that I visited in October 2006, five children had recently been forced to leave school because they were not able to pay the school fees, and, by May 2008, the school fee situation remained largely unchanged.

${ }^{15}$ Note, though, that the objectives for primary education specify that "reading, writing and numeracy" are important "so that graduates can function in their day to day activities," and one of the objectives is to "expose children to various skills and talents so that they can identify their areas of strength” (MOE 2009, 1). 
The MOE, aware of the orphan and poverty problems related to HIV/ AIDS, collaborated with UNICEF to recreate schools as "Centers of Care and Support." A pilot project involving 40 schools was launched in 2006, focusing on building partnerships with the communities, providing psychosocial support, ensuring food security, and implementing basic health and sanitation services (UNICEF 2007). According to teachers, the various initiatives have had "positive effects" on the children's schooling and dropout rate: "before, children were staying at home, or hanging around, and some were begging, trying to get something. Now they attend well" (interview, October 2006). OVC students continued to be expelled, however, for poverty-related reasons. As one civil servant in Lowweld explained, "Some of the OVC are still expelled [for nonpayment of fees] but they [the caregivers] begin to find out that they have rights" (interview, October 2006).

Although protection programs can have a positive impact on children in school, interviewees pointed to two potentially negative side effects. First, the focus on school-based protection programs may neglect attention to protection during school holidays or during prolonged teacher strikes. Local police authorities say that children are often abused during the school holidays. Moreover, in many villages, the majority of children never attended school or has dropped out of school. These children do not benefit from schoolbased protection programs. Second, while school-based protection may encourage some children to stop manual daytime labor (e.g., working in the fields or looking after cattle) in favor of attending school, they may have to take up nighttime labor, including sex work, to earn money needed by their families. According to one police officer, there is a perverse relationship between compulsory schooling, poverty, and sex work, although she was not able to provide direct evidence of her conclusion. Similarly, according to an MOE official: "There is a danger of a perverse effect of denying child labor. . . . Most OVCs can't learn a trade and gain [formal] employment. These children still must put bread on the table, which leads into prostitution" (interview, October, 2006).

Moreover, schools are not functioning as protective agencies in the sense that children are frequently subjected to corporal punishment (Soneson 2005b). Indeed, school-based corporal punishment in inscribed in Swaziland's laws. For instance, section 11 of the 1977 Education Rules states:

1. Corporal punishment shall be administered to boys by the headmaster.

2. Corporal punishment shall be administered to girls only by a female teacher.

3. Corporal punishment shall not be given in public.

4. No cane or stick exceeding 0.83metres (two and a half feet) in length, and 1.5 centimetres (half an inch) in diameter, shall be used for the infliction of corporal punishment.

5. All corporal punishment shall be administered on the buttocks and 
not on other parts of the body. (Masuku 2005, 1)

It is likely that those who have been orphaned by HIV/AIDS and those who live in poverty are more frequently punished than other children. ${ }^{16}$ Teachers and children interviewed confirmed that children are punished for not paying school fees, for not wearing school uniforms, or for coming late to school-often because they had to perform duties at home before classes started (collecting water, caring for siblings, etc.). As noted above, all of these responsibilities are more prevalent among OVG students.

An aid worker in an international NGO said he had tried to dissuade teachers from using corporal punishment, but they had responded that his suggestion was not only wrong, it contradicted what is inscribed in Swazi law. Perhaps because of this legal basis for corporal punishment, relatively few international agency or NGO projects (or government programs) provide training on alternative forms of classroom management and teacher-pupil relations, despite some interviewees' expressing concerns about the negative impact of corporal punishment on children, especially OVC students.

\section{Conclusion}

Children in Namibia and Swaziland face tremendous challenges from high poverty and HIV/AIDS incidence rates. Each country's official curriculum does not include much preparation in life skills and consequently does not effectively address the needs of children's current and future lives. Furthermore, schools can be seen as a hostile environment in terms of the hidden curriculum (beatings and ostracism by teachers and peers). Teachers interviewed expressed that many children drop out of school at least in part because of these factors.

From the interviews emerged at least three different barriers to education. The first two impediments can be categorized as engineering barriers, while the third can be classified as a metaphysical barrier:

Direct cost of schooling: although direct costs for primary and secondary school have theoretically been abolished in both countries, most schools still impose fees (e.g., for education materials, school uniforms, and school infrastructure maintenance).

Opportunity costs: working children are in many cases the main source of income for the family. Replacing the income from children's work may be difficult, especially for child-headed families, but is nevertheless indispensable to ensure the continued schooling for the child.

Social issues: children are often targets for bullying and discrimination

${ }^{16}$ During interviews I noted that the stigma-and psychological abuse-encountered by those with HIV/AIDS in Namibia often seemed less pronounced in Swaziland, maybe because of the very high infection rate. A head teacher noted, "Nobody makes fun of orphans. The rate of dying is so high; I myself feel that I am going to die very soon" (interview, October 2006). 
because of their family situation (being an AIDS orphan, inability to afford school fees, lack of school materials or uniforms). These problems may isolate and stigmatize the children-and may even discourage them from going to or remaining in school. Also, many of the disadvantaged children are unable to attend school regularly, cannot do homework correctly, or cannot arrive at school on time because they need to assist their family in the morning or during the school day. This situation often results in ostracism and harassment by teachers and schoolmates because of what is perceived as the children's insufficient commitment to school. Furthermore, interviewees indicate that corporal punishment is particularly targeted at orphans and vulnerable children for all these reasons.

Both the Namibian and Swaziland governments recognize at least some of the problems that OVC and poor students face (e.g., financial problems and ostracism) and are trying to address them. In many cases, however, the effects of such policies have been inadequate, often because of limited funds to implement them. In both countries, interviewees pointed to a discrepancy between the legal framework of education, in which mechanisms for protection of the most vulnerable exist, and the actual implementation, which is often flawed. For instance, both countries have psychosocial counselors in the schools, who are generally teachers who have received a short in-service training in basic counseling. In most cases, however, the teachers are not compensated nor are they given reduced teaching and administrative duties for the counseling work they do, and thus their impact is weakened.

As argued above, both poverty and HIV/AIDS create conditions that push children to attend irregularly and drop out of school as well as to become involved in child labor, including the WFCL. Many children drop out of school because the burden of HIV/AIDS exacerbates their family's impoverished situation, compelling children to engage in commercial activities (including sex work) in the informal economy. Interview and statistical evidence from both Namibia and Swaziland suggests that grandparents often act as caregivers for orphaned children. In the current stage of the epidemic, the surviving grandparent generation that is unaffected by HIV/AIDS is aging and is increasingly less capable of meeting children's needs (Whalley et al. 2007).

In this context, providing a protective environment involves implementing strategies to keep the poorest children in school and to help children with HIV/AIDS-affected family members to cope. To be protective agencies, schools need to raise awareness and otherwise seek to prevent ill treatment of children (verbal, corporal punishment, and sexual abuse). There is, however, little agreement on how to go about the creation of such a protective environment in schools.

In this article I have described a few government, international organization, and NGO initiatives in Namibia and Swaziland that have focused on 
issues of protection in schools. These examples include engineering solutions (such as providing uniforms, food, and school supplies to children) as well as metaphysical solutions (including creating solidarity clubs and establishing life skills classes). Such education-as-protection initiatives have, however, been small-scale projects rather than fundamental to the functioning and goals of the education system.

Based on the lessons from Namibia and Swaziland, it seems that certain basic strategies could steer schools toward a more protective function. These strategies involve both engineering and metaphysical approaches. As demonstrated by the case studies, the engineering solutions include the termination of the direct cost for basic education for at-risk and vulnerable children and, as much as possible, compensation for their opportunity costs (especially through food distribution schemes). In general, the abolition of the direct costs for all children should be considered. Furthermore, ill-devised policies that may lead to corruption, such as the uniform regulations in Swaziland, should be eliminated.

The case studies also illustrate that metaphysical approaches are important complements to engineering strategies. These approaches include the supervision of children by educators and community members to reduce or prevent adult abuse of children during school time and free time and holidays, together with raising the teachers' awareness and understanding of the plight of OVC students (such as the need for OVC to support the family by fetching water, collecting wood, and care giving). Such awareness raising should also address the issue of corporal punishment in schools, especially when this practice affects disproportionally the most vulnerable. The creation of life skills curricula-and ensuring that schools have the resources to implement them-would complement the teacher training and further address the children's economic and psychological needs. The setup of solidarity circles and the use of other psychosocial tools could help prevent stigmatizing and bullying of the most vulnerable and also, where necessary, heal trauma.

Failure to implement these and similar protective policies may lead large numbers of OVC students to drop out of school and fall into a situation of child labor, thereby continuing an intergenerational cycle of poverty, abuse, and illiteracy. The case studies of Namibia and Swaziland illuminate the issues raised in international policy documents and provide support for the educational reforms they propose to improve the protective function of schools (see UNICEF 2004; EDUCAIDS 2008).

Rather than questioning the aims and goals of education in contexts of poverty and increasing disparities (Noddings 2003), education systems often seem to be characterized by their focus on business as usual (e.g., the most basic engineering issues). It is time to launch a debate on the aims of education and to discuss ways in which schools can work as agents of protection and change rather than mirrors of injustice. Pat Pridmore and Chris Yates 
(2005, 491) found that "the rapidly growing literature on educational responses to HIV and AIDS offers much good advice on how to continue 'business as usual' in the face of the challenges presented by the epidemic." In light of the impact of HIV/AIDS, which has weakened traditional and family safety networks, I argue that schools need to go beyond business as usual. At a minimum, schools should not be an additional negative factor in the lives of vulnerable children. Instead, they should function in a positive way through changed official and hidden curricula. The cases of Namibia and Swaziland demonstrate the need for schools to look into strategies for protecting orphans and vulnerable children and for creating a learning environment that is safe, protective, and friendly for all children.

\section{References}

Bartlett, L. 2008. "Quality Education, Care and Protection: Undertaking a Baseline Study in Five SSA Countries for an Integrated School-Based Model of Quality Education, Care and Protection for Children Affected by HIV and AIDS.” http:// www.tc.columbia.edu/faculty/bartlett/research/quality.html.

Bennell, P., K. Hyde, and N. Swainson. 2002. The Impact of the HIV/AIDS Epidemic on the Education Sector in Sub-Saharan Africa: A Synthesis of the Findings and Recommendations of Three Country Studies. Sussex: Centre for International Education, University of Sussex Institute of Education.

$\rightarrow$ Brown, L., K. Macintyre, and L. Trujillo. 2003. "Interventions to Reduce HIV/AIDS Stigma: What Have We Learned?" AIDS Education and Prevention 15 (1): 49-69.

Creswell, J. W. 1998. Qualitative Inquiry and Research Design: Choosing among Five Traditions. Thousand Oaks, CA: Sage.

CSO (Central Statistical Office). 2007. 2006-2007 Swaziland Demographic and Health Survey. Mbabane: Government of the Kingdom of Swaziland.

Delors, J., A. Ain'am, and I. Amagi. 1996. Learning: The Treasure Within: Report to UNESCO of the International Commission on Education for the Twenty-first Century. Paris: UNESCO.

Dorman, P. 2008. Child Labour, Education and Health: A Review of the Literature. Geneva: International Labor Organization.

Edmonds, C. 2003. Ethical Considerations When Conducting Research on Children in the Worst Forms of Child Labour. Geneva: International Labor Organization.

EDUCAIDS. 2008. EDUCAIDS Technical Briefs. Paris: UNESCO. http://www.unesdoc .unesco.org/images/0015/001584/158436e.pdf\#13.

Foster, G., and J. Williamson. 2000. "A Review of Current Literature of the Impact of HIV/AIDS on Children in Sub-Saharan Africa." AIDS 14 (suppl. 3): S275-S284.

Haihambo-Muetudhana, C., J. Hayden, B. Otaala, and R. F. Zimba. 2002. An Assessment of Services Provided to Children Affected and Infected by HIV/AIDS in Windhoek, Namibia. Windhoek: University of Namibia Press.

$\rightarrow$ Harper, C., R. Marcus, and K. Moore. 2003. "Enduring Poverty and the Conditions of Childhood: Lifecourse and Intergenerational Poverty Transmissions." World Development 31 (3): 535-54. 
He, B. 2006. "Consultancy: A Different Gate to the Field." In Doing Fieldwork in China, ed. M. Heimer and S. Thørgesen. Copenhagen: NIAS Press.

ILO (International Labor Organization). 1999. "Convention concerning the Prohibition and Immediate Action for the Elimination of the Worst Forms of Child Labour." Worst Forms of Child Labor Convention, ILO convention no. 182, Geneva, June 17.

ILO (International Labor Organization). 2006. The End of Child Labour: Within Reach. Global Report under the follow-up to the ILO Declaration on Fundamental Principles and Rights at Work. Geneva: International Labor Office.

ILO/IPEC (International Labor Organization's International Program for the Elimination of Child Labor). 2003. "Facts on the HIV/AIDS Crisis and Child Labour." http://www.wotclef.org/documents/fs_hiv_0303.pdf.

ILO/IPEC (International Labor Organization's International Program for the Elimination of Child Labor). 2009. "About Child Labour.” http://www.ilo.org/ ipec/facts/lang-en/index.htm.

IRIN (Integrated Regional Information Network). 2009. "Swaziland: Growing Number of Children Working." http://www.newsite.irinnews.org/Report .aspx?ReportId $=61535$.

$\rightarrow$ Kobiané, J.-F., A.-E. Calvès, and R. Marcoux. 2005. "Parental Death and Children's Schooling in Burkina Faso." Comparative Education Review 49 (4): 468-89.

LeCompte, M. D., and J. J. Schensul. 1999. Designing and Conducting Ethnographic Research (The Ethnographer's Toolkit, Vol. 1). Walnut Creek, CA: AltaMira.

Lewnes, A. 2005. After-School Programme Opens a "Window of Hope" for Children Dealing with HIV/AIDS. Okalongo, Namibia: UNICEF.

Masuku, T. 2005. “Corporal Punishment Legal." Swazi Observer, September 16. World Corporal Punishment Research (CORPUN) Archives. http://www.corpun.com/ szs00509.htm.

MEC (Ministry of Education and Culture). 1993. Toward Education for All. Windhoek, Namibia: Ministry of Education and Culture.

Merriam, S. B. 1998. Qualitative Research and Case Study Applications in Education. Rev. ed. San Francisco: Jossey-Bass.

MOE (Ministry of Education). 2009. "Swaziland Education System.” http://www.gov $. s z /$ home.asp?pid $=745$.

Namibia Government. 2007. "The Population.” http://www.grnnet.gov.na/aboutnam .html.

Namibia Government. 2008. Report of the 2008 National HIV Sentinel Survey. Windhoek: Ministry of Health and Social Services.

Noddings, N. 2003. Happiness and Education. Cambridge: Cambridge University Press.

Nyamukapaa, C., and S. Gregson. 2005. "Extended Family's and Women's Roles in Safeguarding Orphans' Education in AIDS-Afflicted Rural Zimbabwe." Social Science and Medicine 60 (10): 2155-67.

Postman, N. 1996. The End of Education: Redefining the Value of School. New York: Vintage.

$\rightarrow$ Pridmore, P., and C. Yates. 2005. "Combating AIDS in South Africa and Mozambique: The Role of Open, Distance, and Flexible Learning (ODFL).” Comparative Education Review 49 (4): 490-511. 
Soneson, U. 2005a. Ending Corporal Punishment of Children in South Africa. Pretoria: Save the Children Sweden, Regional Office for Southern Africa.

Soneson, U. 2005b. Ending Corporal Punishment of Children in Swaziland. Johannesburg: Save the Children Sweden, Regional Office for Southern Africa.

Terry, E. 2007. Worst Forms of Child Labor in Namibia: Discussion Paper. Windhoek: Ministry of Labor and Social Welfare and the International Labor Organization.

UNAIDS (Joint United Nations Program on HIV/AIDS). 2002. Sex Work and HIV/ AIDS: UNAIDS Technical Update. Geneva: Joint United Nations Program on HIV/ AIDS.

UNAIDS (Joint United Nations Program on HIV/AIDS). 2006. "Resource Pack on Gender and HIV/AIDS." http://www.unfpa.org/publications/detail.cfm?ID =279.

UNDP (United Nations Development Program). 2008. Human Development Report: Fighting Climate Change; Human Solidarity in a Divided World. New York: UNDP.

UNDP (United Nations Development Program). 2009. Human Development Report: Overcoming Barriers; Human Mobility and Development. New York: UNDP.

UNESCO (United Nations Educational, Scientific and Cultural Organization). 2008. EFA Global Monitoring Report: Education for All by 2015: Will We Make It? Oxford: Oxford University Press.

UNICEF (United Nations Children's Fund). 2004. "Life Skills: Child Friendly Schools." http://www.unicef.org/lifeskills/index_7260.html.

UNICEF (United Nations Children's Fund). 2007. A National Study on Violence against Children and Young Women in Swaziland. Mbabane: UNICEF.

USDOL (U.S. Department of Labor). 2007. "Education Initiative." http://www .dol.gov/ILAB/programs/iclp/technical_assistance_Education_Initiative.htm.

USDOL (U.S. Department of Labor). 2008. U.S. Department of Labor's 2007 Findings on the Worst Forms of Child Labor. Washington, DC: U.S. Department of Labor.

USDOS (U.S. Department of State). 2008. "Background Note on Swaziland." http:// www.state.gov/r/pa/ei/bgn/2841.htm.

Whalley, A., A. Whiteside, and S. Naysmith. 2007. Reviewing "Emergencies" for Swaziland: Shifting the Paradigm in a New Era. Mbabane, Swaziland: NERCHA.

$\rightarrow$ Winthrop, R., and J. Kirk. 2008. "Learning for a Bright Future: Schooling, Armed Conflict, and Children's Well-Being." Comparative Education Review 52 (4): 639-61.

World Bank. 2006. Namibia Country Brief. Washington, DC: World Bank. 